\title{
Preferences for Developing Undergraduate Research in Pakistani Universities: Student Teachers' Perspective
}

\author{
Fayyaz Ahmed Faizi* \\ Muhammad Athar Hussain **
}

\begin{abstract}
Undergraduate Research (UGR) is an important component in the curriculum of good ranking universities at present. It encompasses a continuous process of research engagements during undergraduate studies. Involving undergraduate students in research helps in linking theory to practice, understanding research processes and determining career choices. However, promoting UGR in universities in Pakistan requires proper consideration and planning. This study was aimed at identifying research preferences of undergraduate students and improving UGR in Pakistani universities. As students are the most important stakeholder in UGR, the data were collected from 2168 undergraduate students randomly selected from four large universities in Rawalpindi-Islamabad. The research instrument used was a questionnaire developed, pilot tested and validated before its use in this study. The data were converted into percentages and crosstabs using SPSS to analyze data. We found that undergraduate students expressed strong preference for research involvement and were willing to work any part of the week for gaining research experience. The students preferred field research as compared to research in lab or desk work. The students' views and preferences on crosstabs helped in devising strategies for improving UGR in universities in Pakistan.
\end{abstract}

Key words: career, higher education, improving research, undergraduate research

Head Department of Humanities, COMSATS, Islamabad Campus, Email:

drfayyaz@ comsats.edu.pk

** Assistant Professor, Allama Iqbal Open University, Islamabad. 


\section{Introduction}

Universities at present have an important role in building students' capacity and preparing them to work for sustainable development of the communities through quality education and research (Shiel, Filho, do Paço, \& Brandli, 2016). The university faculty is expected to engage in research and add to the 'existing reservoir of knowledge' (Verdonk, 2013). As regarding students, the MS and $\mathrm{PhD}$ students do research work as a complimentary requirement during the end of their program in which they write research thesis. Before that, the students have little exposure to research work and research-based learning (Faize \& Idrees, 2014). Coming to the undergraduate (UG) level, the research-based engagement hardly exists (Strassburger, 1995). The result is that a large bulk of these students completes their graduation and leaves the universities in the pursuit of professional career without any exposure to research-based activities (Boyer Commission, 1998). This necessitates the demand for introducing a systematic Under Graduate Research (UGR) program in universities for these students.

UGR refers to a program involving under graduate (UG) students to work with their mentors on research project for a six to ten weeks' duration and mostly during summer (Goodland, 1998). However, the research may be conducted during semester as well. Goodland offer a simplistic view of UGR which covers students' involvement during a research endeavour. The Council on Undergraduate Research (CUR) in US defined UGR as students' effort making 'original contributions to disciplinary knowledge'. This makes it different from the knowledge already available and includes a systematic progression towards exploring new knowledge.

According to O'Clock and Rooney (1996), there are two main purposes of involving undergraduate students in research. Firstly, to enable the students learn and understand the methods of doing research and secondly, to create interest and appreciation for academic research. Feeling the need for undergraduate research, a movement was started in the United States to promote undergraduate research in universities. The movement gained momentum and the undergraduate research program is now a necessary part of the curriculum in most of the universities including the world top universities such as University of Berkeley, Boston University, the Georgia Institute of Technology, the University of California, the Massachusetts Institute of Technology (MIT), the University of Michigan, the University of New Hampshire and the University of Oregon. 
According to Yildirim and Ilin (2009), the significance of UGR is well established since last twenty-five years. The period of UG level is a stage where the students are young and active. According to Valderama et al. (2009), the time during which the undergraduate students involve in research project is the peak level of learning for them as they keep applying the knowledge they learnt in the previous semesters. This involvement further helps the students in better understanding the research process (Richmond, 1998, Kardash, 2000) and looking for suitable career choices (Elgren \& Hensel, 2006; Russell, Hancock, \& McCullough 2007). Thus, it is imperative that UG students should be actively involved in some kind of research led activities.

However, UGR is still very weak in universities in Pakistan (Faize \& Idress, 2014). Feeing the importance of strengthening UGR in Pakistani universities, this research study was conducted as preliminary phase for exploring students' perception and choices for involvement in UGR. The perception of students will help in devising strategies for improving UGR in Pakistani universities as well as brining an economic impact through extensive research involvement.

\section{Objectives of the Study}

The objectives of the research study were to:

1. Explore views of undergraduate students on participation in research activities.

2. Find out means to improve involvement of undergraduate students in research.

\section{Methodology}

\section{Design}

The study was descriptive in nature and a survey type study. The data were collected through a questionnaire consisting of items with categorical variables.

\section{Population and Sample}

The population for the present study comprised of all undergraduate students studying in Rawalpindi and Islamabad universities. However, due to time constraint and lack of resources, the researchers randomly selected four universities in Rawalpindi-Islamabad in the first phase. In the second phase, students of UG level from departments of science and 
education (social science) were selected from each university through convenient sampling by visiting each university and requesting the faculty members to allow collection of data during their classes. The reason for using convenient sampling was to ensure that maximum number of students could be involved in the study for improving data credibility (Tansey, 2007). The total number of students contacted were 2168. However, for each item, the number of missing cases were different which were eliminated during analysis for each case. The responses of the students were latter categorized discipline wise for comparative analysis of science versus social science students.

\section{Instrument}

The preferences of UG students were explored through a questionnaire which was validated by four experts in the relevant field. In the light of suggestions made by experts and through the findings of pilot test, the questionnaire was refined and improved. The responses of the students were taken as frequency measure which relates to nonparametric data. The normal distribution does not apply to nonparametric data. Thus, Chi-square test was used to find relationship between the students' responses program wise (Gravetter \& Wallnau, 2016). The responses of students were converted into percentages and cross tabulation using chi square test at .05 significance level to interpret students' choice program wise (science versus social science students). The items helped in identifying preferences on two constructs: students' attitude towards research involvement (table 2, 3 and 4) and time preference for research (table 5, 6, 7).

\section{Results and Discussion}

The study comprised of students from different disciplines. In order to make analysis more meaningful, the students were grouped into science and social science disciplines after collection of data (Table 1). 
Table 1

Program wise students detail from each university

\begin{tabular}{lllll}
\hline & & \multicolumn{2}{l}{ Program Section } & \\
& & Science & Social Sciences & Total \\
\hline Name of University & COMSATS & 398 & 48 & 446 \\
& Arid & 204 & 308 & 512 \\
& NUML & 126 & 566 & 692 \\
Total & Szabist & 130 & 310 & 440 \\
& & 858 & 1232 & 2090 \\
\hline
\end{tabular}

Table 1 shows the total number of science students selected in the study were 858 and the number of students from social sciences were 1232 .

Table 2

Students involvement in research activities during studying research course

\begin{tabular}{|c|c|c|c|c|c|}
\hline & & & \multicolumn{2}{|c|}{ Program Section } & \multirow[b]{3}{*}{ Tota } \\
\hline & & & & Social & \\
\hline & & & Science & Science & \\
\hline \multirow{4}{*}{$\begin{array}{l}\text { Research activity during } \\
\text { studying research course }\end{array}$} & Yes & Count & 310 & 690 & 1000 \\
\hline & & $\%$ & $38.2 \%$ & $57.0 \%$ & $49.5 \%$ \\
\hline & No & Count & 502 & 520 & 1022 \\
\hline & & $\%$ & $61.8 \%$ & $43.0 \%$ & $50.5 \%$ \\
\hline \multirow[t]{2}{*}{ Total } & & Count & 812 & 1210 & 2022 \\
\hline & & $\%$ of Total & $40.2 \%$ & $59.8 \%$ & $100.0 \%$ \\
\hline
\end{tabular}

The data from table 2 shows that the UG students expressed their involvement in research related activities during the time when they studied research method course. The views were divided program wise. Majority of science students responded that they were not involved in research activity while the students in social science responded positively. This was against expectations as we expected that science students would be involved in greater research. There was significant association between performing research activity and students' program wise distribution $\left(\mathrm{X}^{2}=69.05, \mathrm{p}<.05\right)$. Involving students in research activity is very necessary during the teaching of research methods. Behar-Horenstein et al. (2010) found that students have problems in understanding research skills and there is a need to involve these students to help them improve their understandings and minimize errors. 
Table 3

Students' plan after passing their Bachelor program

\begin{tabular}{lccccc}
\hline & & \multicolumn{3}{c}{ Discipline } \\
& & & Social & \\
& & & Science & Science & Total \\
\hline Future plan after & Enrol for MS/PhD & Count & 462 & 516 & 978 \\
Bachelors & & $\%$ & $62.9 \%$ & $49.4 \%$ & $55.0 \%$ \\
\cline { 3 - 5 } & Opt for job & Count & 240 & 366 & 606 \\
& \multirow{2}{*}{ Any other } & $\%$ & $32.7 \%$ & $35.1 \%$ & $34.1 \%$ \\
\cline { 3 - 5 } & & Count & 32 & 162 & 194 \\
& & $\%$ & $4.4 \%$ & $15.5 \%$ & $10.9 \%$ \\
\cline { 3 - 5 } Total & Count & 734 & 1044 & 1778 \\
& & $\%$ of Total & $41.3 \%$ & $58.7 \%$ & $100.0 \%$ \\
\hline $\mathrm{X} 2=64.95, \mathrm{p}<.05$ & & & &
\end{tabular}

Table 3 shows that the majority students expressed to continue their studies after passing their bachelor program $(55 \%)$. The value of Chi square explains that there is a significant relationship between students' future plan and their discipline $\left(\mathrm{X}^{2}=64.95, \mathrm{p}<.05\right)$. This is also helpful in planning for future needs of these students. The students' response of continuing to graduate studies was very encouraging. Kitutu et al. (2016) also found that the UG students expressed to continue post graduate education. This is in line with the findings of John and Creighton (2011) that prior research experience is not necessary for enrolling in post graduate education. The science students have a greater percentage for getting admission in graduate studies than non-science students. The finding suggests that the universities in Pakistan and the government should plan for accommodating a large number of students into graduate programs on emergency basis. Some students expressed to search for jobs after their graduation but these responses were not significant. 
Table 4

Students' preference for type of research work

\begin{tabular}{lllccc}
\hline & & \multicolumn{3}{c}{ Discipline } \\
& & & \multicolumn{3}{c}{ Social } \\
Sype of research work & field work & Count & Science & Science & Total \\
\cline { 2 - 5 } & & 510 & 798 & 1308 \\
& lab work & Count & $60.6 \%$ & $65.3 \%$ & $63.4 \%$ \\
\cline { 2 - 5 } & & $\%$ & 240 & 264 & 504 \\
& desk work & Count & $92.5 \%$ & $21.6 \%$ & $24.4 \%$ \\
\hline & & $\%$ & $10.9 \%$ & $13.1 \%$ & $12.2 \%$ \\
\hline Total & & Count & 842 & 1222 & 2064 \\
& & $\%$ of Total & $40.8 \%$ & $59.2 \%$ & $100.0 \%$ \\
\hline X2 $=13,39, \mathrm{p}<05$ & & & &
\end{tabular}

The preference for type of research work can be predicted from students' program $\left(\mathrm{X}^{2}=13.39, \mathrm{p}<.05\right)$. Both the science and social science students preferred research in the field followed by research in the lab. The research on desk (such as documentary analysis, searching literature, writing literature etc.) was not preferred by students in both the groups. Slattery et al. (2016) found that students who like to do lab research when involved in research projects changed their preference to field research. It seems that university students do not prefer lab research or desk research as they are somehow involved in such kind of activities during semester work. The preference for field work shows that such research involvement is less in Pakistani universities and there is a need for incorporating field visits and research in the curriculum (Faize \& Dahar, 2011).

Table 5.

Students' preferred duration for involvement as research interns

\begin{tabular}{llcccc}
\hline & & & Discipline & & \\
& & & Social & \\
& & & Science & Science & Total \\
\hline Project duration & Up to one month & Count & 332 & 519 & 851 \\
& & $\%$ & $39.7 \%$ & $42.6 \%$ & $41.4 \%$ \\
\cline { 2 - 5 } & Up to four months & Count & 216 & 314 & 530 \\
& & $\%$ & $25.8 \%$ & $25.8 \%$ & $25.8 \%$ \\
\cline { 2 - 5 } & Over four months & Count & 288 & 385 & 673 \\
& & $\%$ & $34.4 \%$ & $31.6 \%$ & $32.8 \%$ \\
\hline Total & & Count & 836 & 1218 & 2054 \\
& & $\%$ of Total & $40.7 \%$ & $59.3 \%$ & $100.0 \%$ \\
\hline $\mathrm{X} 2=2.23, \mathrm{p}>.05$ & & & &
\end{tabular}


Table 5 indicates students' preferences for project duration. The responses of the students were divided. The value of chi square was $X^{2}=$ $2.23, \mathrm{p}>.05$, which shows that there is no significant relationship between preferred project duration and students' discipline. Thus, it is difficult to determine the preferred project duration of students. $41.4 \%$ of students preferred short duration of research participation (one month). One reason for this may be that these students do not want to continue with excess work of research besides the routine course workload. The students did not prefer duration up to four months. Surprisingly, 32.8\% students also preferred project duration over four months. May be these students are thinking of economic benefits associated with project activities.

Table 6

Students' preferred time of year for research involvement

\begin{tabular}{|c|c|c|c|c|c|}
\hline & & & \multicolumn{2}{|c|}{ Discipline } & \multirow[b]{2}{*}{ Total } \\
\hline & & & Science & Science & \\
\hline \multirow[t]{4}{*}{ Preferred time of year } & during semester & Count & 366 & 642 & 1008 \\
\hline & & $\%$ & $43.9 \%$ & $52.7 \%$ & $49.1 \%$ \\
\hline & summer vacation & Count & 468 & 576 & 1044 \\
\hline & & $\%$ & $56.1 \%$ & $47.3 \%$ & $50.9 \%$ \\
\hline \multirow[t]{2}{*}{ Total } & & Count & 834 & 1218 & 2052 \\
\hline & & $\%$ of Total & $40.6 \%$ & $59.4 \%$ & $100.0 \%$ \\
\hline
\end{tabular}

The students expressed their choice of working in research project during semester or during summer vacation. The science students preferred summer vacation while the social science students preferred research participation during semester. Thus, the students' preference can be judged from their program $\left(\mathrm{X}^{2}=15.42, \mathrm{p}<.05\right)$. However, involving UG students during semester would requires less time such as four hours a week due to academic load on students (Jamerson, Fish, \& Frandsen, 2011). In comparison, they can be involved full-time in research project and training during summer (Cepanec, Clarke, Plohman, \& Gerard, 2013). It shall be taken into consideration that involving students during summer research program is more effective as compared to involvement during semester (Slattery et al. 2016). 
Table 7

Students' preferred days for research involvement

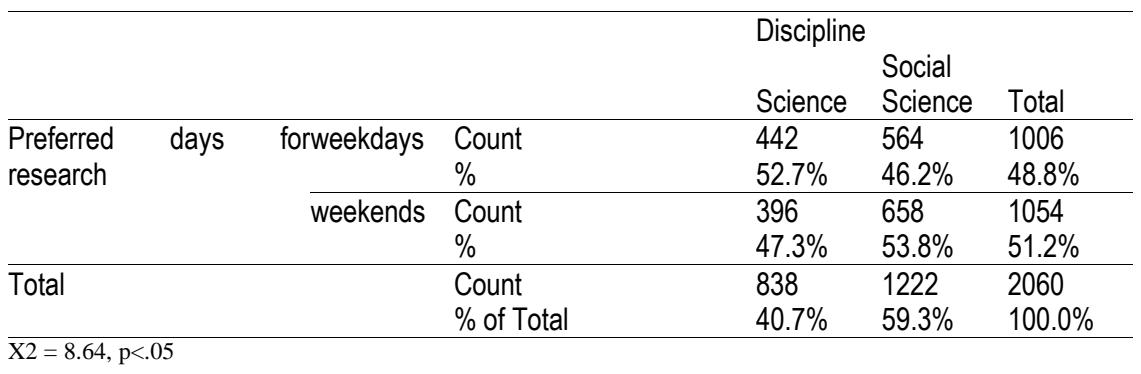

Table 7 shows students preferred days for research involvement. There existed a significant relationship between preferred days and discipline $\left(\mathrm{X}^{2}=8.64, \mathrm{p}<.05\right)$. The students in each discipline differed on the days preferred for research involvement. The science students preferred weekdays $(52.7 \%)$ while, the social science students preferred weekends for research involvement (53.8\%). Perhaps, the science students know that research in science requires lab facilities which are available during the weekdays while, the research in social science can be performed any days.

The students' preferences from this study can be modelled for improving UGR in Pakistani universities. In planning for UGR, the teacher should properly plan for incorporating research related tasks in research course. This will provide students a practical way of learning research skills and processes. Most importantly, the students prefer field research more as compared to research in the lab or desk research. The faculty mentor shall plan research tasks and activities that may require field visits and excursions as this is the most preferred research by students while there shall be minimum task related to desk work.

The faculty mentor shall involve the students in small duration projects as the longer duration project is not preferred by students. The students can be involved during summer vacation or during semester in research related tasks. In this direction, the faculty mentor shall seek the views of students and involve them according to their preference. However, research involvement during summer is more effective than involvement during semester due to academic load on students. The students may be involved on weekdays or during weekends. In this direction, the science students prefer weekdays while the social science students prefer weekends. 


\section{Conclusion}

This research aimed at improving UGR in universities in Pakistan. One of the important components of UGR is motivating and involving UG students. There are obstacles to UGR from faculty, university administration and even from students due to lack of awareness regarding the importance of UGR (Zou, 2010). In this direction, it is imperative to explore students' perception towards research based engagements. The students in this study expressed their research preferences for different activities which shows the level of interest for research based involvement. The universities' administration, supervisors and HEC shall take into consideration these preferences and choices when planning for engaging students in UGR.

\section{References}

Behar-Horenstein, L. S., Roberts, K. W., \& Dix, A. C. (2010). Mentoring undergraduate researchers: An exploratory study of students' and professors' perceptions. Mentoring \& Tutoring: Partnership in Learning, 18(3), 269-291.

Boyer Commission (1998). Reinventing undergraduate education: A blueprint for America's research universities. Stony Brook: State University of New York at Stony Brook.

Cepanec, D., Clarke, D., Plohman, J. \& Gerard, J. (2013). Engaging undergraduate nursing students in research: The students' experience of a summer internship program. Journal of Nursing Education, 52, (8), 466-469.

Elgren, T., \& Hensel, N. (2006). Undergraduate research experiences: Synergies between scholarship and teaching. Peer Review, 8(1), 4-7.

Faize, F. A., \& Idrees, S. (2014). Undergraduate research is getting harder-not for Pakistani students. European Scientific Journal, 10(1), 425-434.

Faize, F.A. \& Dahar, M.A. (2011). Physics teachers' competency in practical skills- a comparison of ' $\mathrm{O}$ ' Level and Federal Board students' views in Pakistan. European Journal of Social Sciences. 19(4), 555-560.

Goodland, S. (1998). Research Opportunities for Undergraduates. Studies in Higher Education, 23(3), 349.

Gravetter, F.J., Wallnau, L.B., (2016), Statistics for the behavioral sciences, 10th ed. Cengage Learning, Boston. 
Jamerson, P., Fish, A. \& Frandsen, G. (2011). Nursing student research assistant program: A strategy to enhance nursing research capacity building in a Magnet status pediatric hospital. Applied Nursing Research, 24, 110-113.

John, J., \& Creighton, J. (2011). Researcher development: the impact of undergraduate research opportunity programmes on students in the UK. Studies in Higher Education, 36(7), 781-797.

Kardash, C. M. (2000). Evaluation of undergraduate research experience: Perceptions of undergraduate interns and their faculty mentors. Journal of educational psychology, 92(1), 191.

Kitutu, J., McCall, M., Findle, R., Mahmoud, K. F., \& Greene, W. B. (2016). Beyond one term of mentoring: A new approach to the research mentorship of undergraduate students. International Journal of Nursing Sciences, XXX, 1-8.

O’Clock, P.M. \& Rooney, C.J. (1996). Exposing undergraduates to research through a mentoring program. Journal of Accounting Education, 14(3), 331-346.

Richmond, G. (1998). Scientific apprenticeship and the role of public schools: General education of a better kind. Journal of Research in Science Teaching, 35(6), 583-587

Russell, S.H., Hancock, M.P. \& McCullough, J. (2007). Benefits of undergraduate research experiences. Science, 316(5824), 548-549.

Shiel, C., Filho, W., do Paço, A., \& Brandli, L. (2016). Evaluating the engagement of universities in capacity building for sustainable development in local communities. Evaluation and program planning, 54, 123-134.

Slattery, M. J., Logan, B. L., Mudge, B., Secore, K., von Reyn, L. J., \& Maue, R. A. (2016). An Undergraduate Research Fellowship Program to Prepare Nursing Students for Future Workforce Roles. Journal of Professional Nursing. http://dx.doi.org/10.1016/j.profnurs.2016.03.008

Strassburger, J. (1995). Embracing undergraduate research. American Association of Higher Education Bulletin, 47(9), 3-5.

Tansey, O. (2007). Process tracing and elite interviewing: a case for nonprobability sampling. PS: Political Science \& Politics, 40(4), 765-772.

Valderama, E., Rullan, M., Sanchez, F., Pons, J., Mans, C., Gine, F., Jimenez, L., Peig, E. (2009). Guidelines for the final year project assessment in engineering. $39^{\text {th }}$ ASEE/IEEE Frontiers in Education Conference, October 18-21, 2009, San Antonio, Spain.

Verdonk, P. (2013). The Stylistics of Poetry: Context, cognition, discourse, history. A\&C Black. 
Yildirim, R. \& Ilin, G. (2009). Tutors' and students' perceptions of what makes a good undergraduate research paper. Procedia Social and Behavioral Sciences, 1, 1636-1640.

Zou, Y. J. (2010). Designing undergraduate research through computer science teaching. In Proceedings of the International Multi Conference of Engineers and Computer Scientists.

Received on: June, 11, 2016

Revised on: November 28, 2016

Accepted on: December 28, 2016 